\title{
New records and geographic distribution map of Pseudopaludicola pocoto (Anura: Leptodactylidae: Leiuperinae) in Northeastern Brazil
}

\author{
Charles de Sousa Silva ${ }^{1,2}$, Igor Joventino Roberto ${ }^{3}$, Robson Waldemar Ávila ${ }^{1,2}$ \& \\ Drausio Honorio Morais ${ }^{4}$
}

(1) Universidade Regional do Cariri - Campus do Pimenta, Centro de Ciências Biológicas e da Saúde, Laboratório de Herpetologia, Rua Coronel Antônio Luiz Pimenta 1161, Crato 63105-000, Ceará, Brazil. E-mail: charles.sousa.barroso@gmail.com

(2) Universidade Regional do Cariri - Campus do Pimenta, Departamento de Química Biológica, Programa de Pós-Graduação em Bioprospecção Molecular, Rua Coronel Antônio Luiz Pimenta 1161, Crato 63105000, Ceará, Brazil.

(3) Universidade Federal do Amazonas, Departamento de Biologia, Programa de Pós-graduação em Zoologia, Avenida General Rodrigo Octávio 6200, Manaus 69077-000, Amazonas, Brazil. E-mail: igorjoventino@yahoo.com.br

(4) Universidade Federal Rural da Amazônia, PA 275, km 13, zona Rural, Parauapebas 68515-000, Pará, Brazil. E-mail: drmoraisvt@gmail.com

Silva C.S., Roberto I.J., Ávila R.W. \& Morais D.H. (2017) New records and geographic distribution map of Pseudopaludicola pocoto (Anura: Leptodactylidae: Leiuperinae) in Northeastern Brazil. Pesquisa e Ensino em Ciências Exatas e da Natureza, 1(2): 131-135.

Novos registros e mapa de distribuição geográfica de Pseudopaludicola pocoto (Anura: Leptodactylidae: Leiuperinae) no Nordeste do Brasil

Resumo: Fornecemos novos registros e um mapa de distribuição geográfica atualizado de Pseudopaludicola pocoto Magalhães, Loebmann, Kokubum, Haddad \& Garda, 2014 para os estados brasileiros do Ceará, Rio Grande do Norte e Pernambuco. O presente trabalho auxilia a preencher lacunas na distribuição desta espécie descrita para o domínio Caatinga, o que pode ser útil em futuros planos de conservação.

Palavras chave: Amphibia, Caatinga, neotrópicos, Semi-árido.

Abstract: We provide new records and an updated geographic distribution map of Pseudopaludicola pocoto Magalhães, Loebmann, Kokubum, Haddad \& Garda, 2014 for the Brazilian states of Ceará, Rio Grande do Norte and Pernambuco. The present work helps to fill gaps in distribution of this recently described species in Caatinga Biome, which can be useful in future conservation plans.

Key words: Amphibia, Caatinga, neotropics, Semiarid.

Frog genus Pseudopaludicola Miranda-Ribeiro, 1926 constitute a basal taxon within Leptodactylidae Werner, 1896, subfamily Leiuperinae Werner, 1896 (Pyron et al. 2011), comprising currently 21 species (Frost 2017). They are widely distributed in South America, from northern Argentina to east of Andes in Venezuela, being associated to open formations close to Tropical forests, such as Chaco, Pampas, Cerrado and Caatinga (Frost 2017). In Brazil, the genus is represented by 19 species (Lantyer-Silva et al. 2016), five of which known from Caatinga: P. mystacalis (Cope, 1887), P. ternetzi Miranda-Ribeiro, 1937, P. parnaiba Roberto, Cardozo \& Avila, 2013, P. pocoto Magalhães, Loebmann, Kokubum, Haddad \& Garda, 2014 and 
P. jaredi Andrade, Magalhães, Nunes-de-Almeida, Veiga-Menoncello, Santana, Garda, Loebmann, Recco-Pimentel, Giaretta \& Toledo, 2016, the latter has the narrower distribution, restricted to the Serra das Flores mountain range in the Planalto da Ibiapaba, in the State of Ceará, and in the Floresta Nacional de Nísia Floresta, in the state of Rio Grande do Norte; while $P$. mystacalis and $P$. pocoto have wider geographic distribution within the Caatinga (Loebmann et al. 2010; Magalhães et al. 2014; Pansonato et al. 2014; Andrade et al. 2016; Caldas et al. 2016).

Pseudopaludicola pocoto is widespread in Caatinga Domain, in the states of Ceará (Magalhães et al. 2014), Paraíba (Lantyer-Silva et al. 2016), Pernambuco (Lantyer-Silva et al. 2016; Pereira et al. 2015), Piauí (Silva et al. 2015), Rio Grande do Norte (Magalhães et al. 2014) and Bahia (Andrade et al. 2017). The record of the species from the Atlantic Forest in the state of Minas Gerais evidenced a large distributional gap for the species that needs investigations regarding its occurrence (Andrade et al. 2015).

In northeastern Brazil, Pseudopaludicola pocoto is known to occur in ten municipalities from Ceará (Magalhães et al. 2014; Santana et al. 2015; Roberto \& Loebmann 2016), two of them in the north, Fortaleza $\left(03^{\circ} 43^{\prime} \mathrm{S}, 38^{\circ} 32^{\prime} \mathrm{W}\right)$ and Pacatuba $\left(03^{\circ} 59^{\prime} \mathrm{S}, 38^{\circ} 37^{\prime} \mathrm{W}\right)$, two in the west, Santa Quitéria $\left(04^{\circ} 19^{\prime} \mathrm{S}, 40^{\circ} 09^{\prime} \mathrm{W}\right)$ and Nova Russas $\left(04^{\circ} 42^{\prime} \mathrm{S}, 40^{\circ} 33^{\prime} \mathrm{W}\right)$, three along the Jaguaribe River Valley, Jaguaribe $\left(05^{\circ} 53^{\prime} \mathrm{S}, 38^{\circ} 37^{\prime} \mathrm{W}\right)$, Limoeiro do Norte $\left(05^{\circ} 08^{\prime} \mathrm{S}, 38^{\circ} 05^{\prime} \mathrm{W}\right)$ and Morada Nova $\left(05^{\circ} 06^{\prime} \mathrm{S}, 38^{\circ} 22^{\prime} \mathrm{W}\right)$, and the remaining in the south Barbalha $\left(07^{\circ} 18^{\prime} \mathrm{S}, 3^{\circ} 18^{\prime} \mathrm{W}\right)$, Jati $\left(07^{\circ} 41^{\prime} \mathrm{S}\right.$, $\left.39^{\circ} 00^{\prime} \mathrm{W}\right)$ and Missão Velha $\left(07^{\circ} 14^{\prime} \mathrm{S}, 39^{\circ} 08^{\prime} \mathrm{W}\right)$. From the state of Rio Grande do Norte: municipalities of Macaíba (05 $\left.51^{\circ} \mathrm{S}, 3^{\circ} 21^{\prime} \mathrm{W}\right)$ and Serra Negra do Norte (06 $\left.{ }^{\circ} 39^{\prime} \mathrm{S}, 37^{\circ} 24^{\prime} \mathrm{W}\right)$; state of Paraíba: municipalities of Patos $\left(07^{\circ} 01^{\prime} \mathrm{S}, 3^{\circ} 16^{\prime} \mathrm{W}\right)$ and Serra de Santa Catarina $\left(07^{\circ} 89^{\prime} \mathrm{S}\right.$, $\left.38^{\circ} 17^{\prime} \mathrm{W}\right)$; and Pernambuco: municipalities of Betânia $\left(08^{\circ} 16^{\prime} \mathrm{S}, 38^{\circ} 02^{\prime} \mathrm{W}\right)$ and Serrita $\left(07^{\circ} 56^{\prime} \mathrm{S}\right.$, 39²17'W) (Magalhães et al. 2014; Pereira et al. 2015; Caldas et al. 2016).

Herein, we provide 12 new records of Pseudopaludicola pocoto in Ceará, Rio Grande do Norte and Pernambuco states, with an updated geographic distribution map. Fieldwork took place in Caatinga remnants from October 2010 to February 2014 in the states of Ceará, Rio Grande do Norte and Pernambuco. Frogs were collected manually, euthanized with a SodiumThiopental solution, fixed in $10 \%$ formalin and placed in vials of $70 \%$ ethanol. Amphibians were collected according to authorization for activities with scientific purpose - ICMBio/SISBio $\mathrm{N}^{\circ}$ 29613-1; 55467-1 were deposited in the Coleção Herpetológica da Universidade Regional do Cariri (URCA-H), Crato, Ceará (see Appendix).

Records of Pseudopaludicola pocoto belongs to ten municipalities in Ceará state: Acopiara (06 20 'S, 39 $\left.50^{\circ} \mathrm{W}\right)$, Mauriti $\left(07^{\circ} 22 \mathrm{~S}, 38^{\circ} 38^{\prime} \mathrm{W}\right)$, Aiuaba $\left(06^{\circ} 65^{\prime} \mathrm{S}, 4^{\circ} 13^{\prime} \mathrm{W}\right)$, Banabuiú $\left(05^{\circ} 18^{\prime} \mathrm{S}, 38^{\circ} 55^{\prime} \mathrm{W}\right)$, Barro $\left(07^{\circ} 17^{\prime} \mathrm{S}, 38^{\circ} 78^{\prime} \mathrm{W}\right)$, Farias Brito $\left(06^{\circ} 78^{\prime} \mathrm{S}, 39^{\circ} 53^{\prime} \mathrm{W}\right)$, Jaguaruana $\left(04^{\circ} 79^{\prime} \mathrm{S}\right.$, $\left.37^{\circ} 86^{\prime} \mathrm{W}\right)$, Tauá $\left(06^{\circ} 00^{\prime} \mathrm{S}, 40^{\circ} 17^{\prime} \mathrm{W}\right)$, Várzea Alegre $\left(06^{\circ} 47^{\prime} \mathrm{S}, 3^{\circ} 17^{\prime} \mathrm{W}\right)$ and Juazeiro do Norte $\left(07^{\circ} 12^{\prime} \mathrm{S}, 39^{\circ} 18^{\prime} \mathrm{W}\right)$. For the state of Pernambuco there are records from municipality Exu $\left(07^{\circ} 57^{\prime} \mathrm{S}, 3^{\circ} 9^{\circ} \mathrm{W}\right)$ and a new record from Rio Grande do Norte state, Ceará Mirim municipality (05'38'S, 36 $\left.25^{\circ} \mathrm{W}\right)$.

Many specimens were identified in the field based on advertisement calls, and the remaining were identified from preserved specimens, which fits well with the characteristics given in the original description by Magalhães et al. (2014): cream vocal sac with longitudinal folds, absence of T-shapped finger tips, short legs and complete abdominal fold (Figure 1).

Our study filled some gaps of the geographic distribution of Pseudopaludicola pocoto, especially in the state of Ceará (Figure 2). Despite the record of the species in the Atlantic Forest of Minas Gerais state (Andrade et al. 2015), in the state of Ceará, it's found in the coastal zone, in dry forests, but mostly in the Caatinga sensu strictu areas, however, until then, never registered in the humid forests "Brejos de Altitude".

Pseudopaludicola pocoto seems to be the most widespread species of the genus in the Caatinga. Still, there is a need of more wider geographic sampling of the genus in the Caatinga and surrounding areas, specially using acoustic survey techniques, associated with natural history data collection and molecular research, to help elucidate the geographic boundaries and 
evolution history of the genus in the Caatinga, a biome of a diverse and complex evolutionary history of its biodiversity (Werneck et al. 2015; Thomé et al. 2016).

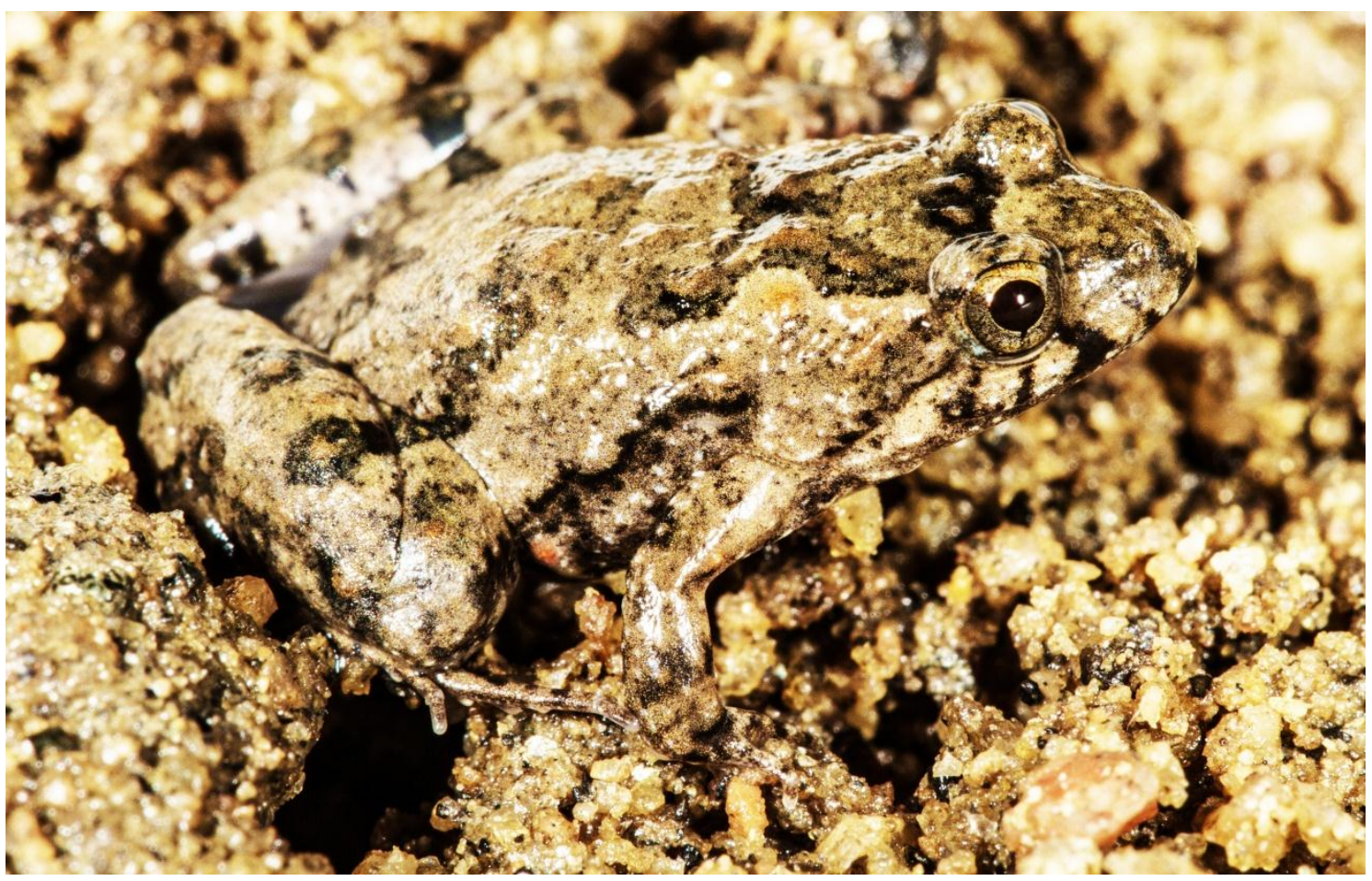

Figure 1. Pseudopaludicola pocoto collected in municipality Aiuaba, Ceará, Brazil (Photo: Drausio H. Morais).

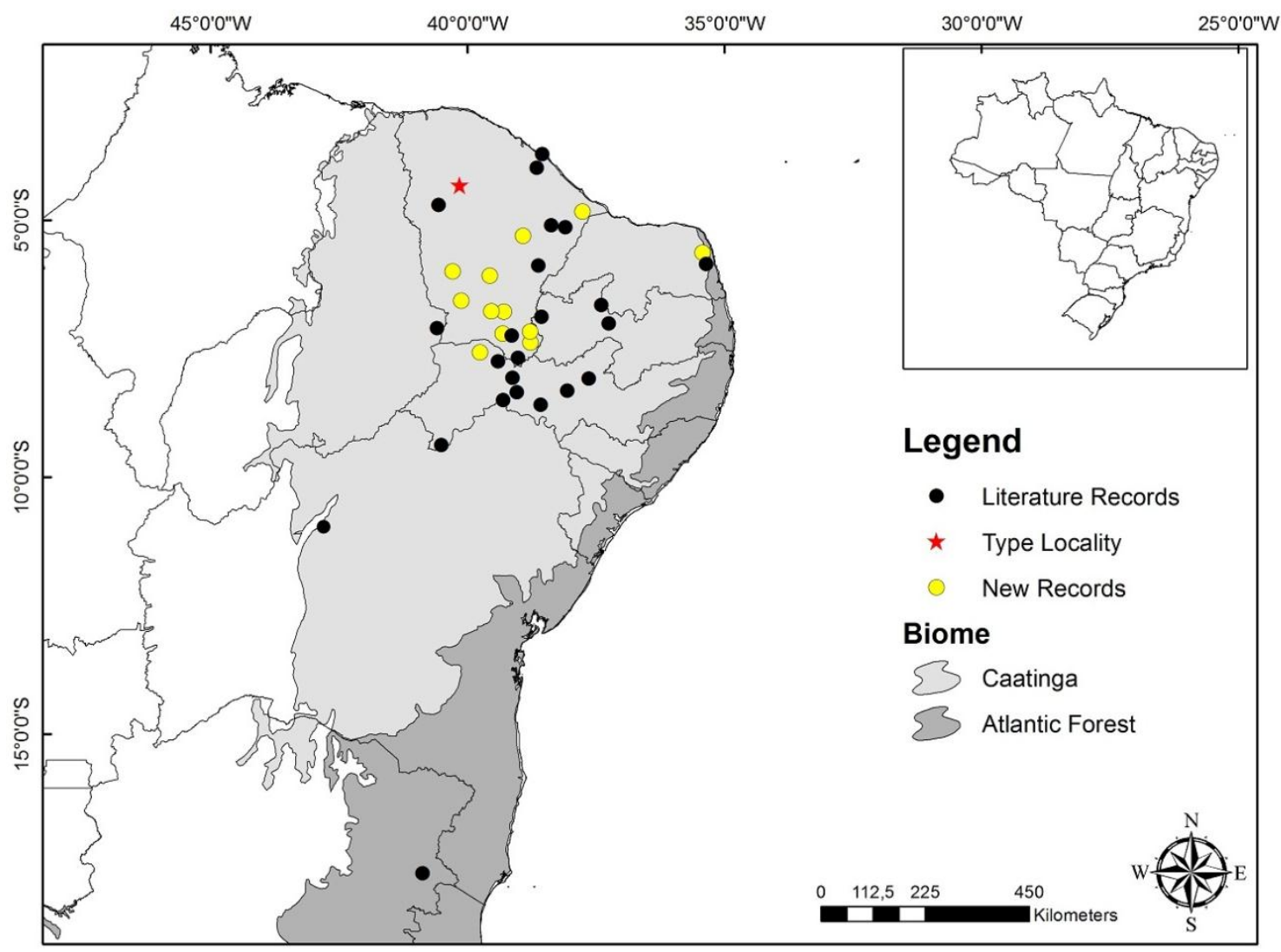

Figure 2. Geographic distribution of Pseudopaludicola pocoto in northeast Brazil. 


\section{Appendix}

The specimens used in this study are preserved in the Coleção Herpetológica da Universidade Regional do Cariri (URCA-H), Crato, Ceará. Here we provide the voucher number of each specimen. Pseudopaludicola pocoto: 105, 1766, 3075, 3185, 3233, 3987, 3993, 4452, 4918, 6936, 11113, 11874.

\section{Acknowledgments}

Thanks to Fundação Cearense de Apoio ao Desenvolvimento Científico e Tecnológico (FUNCAP) for the financial support. To Conselho Nacional de Desenvolvimento Científico e Tecnológico (CNPq) for a research grant to RWA (303622/2015-6) and DHM (150183/2016-0). To the members of the laboratory of herpetology at the Universidade Regional do Cariri for field work assistance. To AFSN for suggestions in the manuscript. To HFO for map elaboration. We are grateful to the anonymous reviewers for critically reviewing the manuscript.

\section{References}

Andrade F.S., Magalhães F.M., Leite F.S.F., Carvalho T.F., Bernardes C.S. \& Giaretta A.A. (2017) First record of Pseudopaludicola pocoto Magalhães, Loebmann, Kokubum, Haddad \& Garda, 2014 (Anura, Leptodactylidae, Leiuperinae) in Bahia state, Northeastern Brazil, with further data on its advertisement call. Check List, 13: 2047.

Andrade F.S., Magalhães F.M., Nunes-de-Almeida C.H.L., Veiga-Menoncello A.C.P., Santana D.J., Garda A.A., Loebmann D., Recco-Pimentel S.M., Giaretta A.A. \& Toledo L.F. (2016) A new species of long-legged Pseudopaludicola from Northeastern Brazil (Anura, Leptodactylidae, Leiuperinae). Salamandra, 52: 107-124.

Andrade I.S., Barros L.C.S., Oliveira A.F.S., Juncá F.A. \& Magalhaes F.M. (2015) Distribution extension of Pseudopaludicola pocoto Magalhães, Loebmann, Kokubum, Haddad \& Garda, 2014 (Anura: Leptodactylidae: Leiuperinae) in state of Minas Gerais, Brazil. Herpetology Notes, 8: 227-229.

Caldas F.L.S., Costa T.B., Laranjeiras D.O., Mesquita D.O. \& Garda A.A. (2016) Herpetofauna of protected areas in the Caatinga V: Seridó Ecological Station (Rio Grande do Norte, Brazil). Check List, 12(4): 1-14. doi: http://dx.doi.org/10.15560/12.4.1929

Frost D.R. (2017) Amphibian species of the world: an online reference. Version 6.0. Available at http://research.amnh.org/ herpetology/amphibia/index.html (Accessed on 15/01/2016).

Lantyer-Silva A.S.F., Matos M.A., Gogliath M., Marciano-Jr E. \& Nicola P.A. (2016) New records of Pseudopaludicola pocoto Magalhães, Loebmann, Kokubum, Haddad \& Garda, 2014 (Amphibia: Anura: Leptodactylidae) in the Caatinga Biome, Brazil. Check List, 12: 1989.

Loebmann D. \& Haddad C.F.B. (2010) Amphibians and reptiles from a highly diverse area of the Caatinga domain: composition and conservation implications. Biota Neotropica, 10: 227-256.

Magalhães F.M., Loebmann D., Kokubum M.N.C., Haddad C.F.B. \& Garda A. (2014) A new species of Pseudopaludicola (Anura: Leptodactylidae: Leiuperinae) from Northeastern Brazil. Herpetologica, 70: 77-88.

Pansonato A., Mudrek J.R., Simioni F., Martins I.A. \& Strüssmann C. (2014) Geographical variation in morphological and acoustic traits of Pseudopaludicola mystacalis (Cope, 1887) and a reassessment of the taxonomic status of Pseudopaludicola serrana Toledo, 2010 (Anura: Leptodactylidae: Leiuperinae). Advances in Zoology, 563165: 1-13.

Pereira E.N, Teles M.J.L. \& Santos E.M. (2015) Herpetofauna em remanescente de Caatinga no Sertão de Pernambuco, Brasil. Boletim do Museu de Biologia Mello Leitão, 37: 29-43.

Pyron A.R. \& Wiens J.J. (2011) A large-scale phylogeny of Amphibia including over 2800 species, and a revised classification of extant frogs, salamanders, and caecilians. Molecular Phylogenetics and Evolution, 61: 543-583. 
Roberto I.J. \& Loebmann D. (2016) Composition, distribution patterns, and conservation priority areas for the Herpetofauna of the State of Ceará, Northeastern Brazil. Salamandra, 52: 134152.

Santana D.J., Mângia S., Silveira-Filho R.R., Barros L.C.S., Andrade I., Napoli M.F., Juncá F.A. \& Garda A.A. (2015) Anurans from the middle Jaguaribe River Region, Ceará State, Northeastern Brazil. Biota Neotropica, 15: 1-8.

Silva I.C., Lima M.S.C.S., Santos M.C.O., Souza P.S. \& Pederassi J. (2015) Geographic distribution: Pseudopaludicola pocoto. Herpetological Review, 46: 213.

Thomé M.T.C., Sequeira F., Brusquetti F., Carstens B., Haddad C.F.B., Rodrigues M.T. \& Alexandrino J. (2016) Recurrent connections between Amazon and Atlantic forests shaped diversity in Caatinga four-eye frogs. Journal of Biogeography, 43: 1045-1056.

Werneck F.P., Leite R.N., Geurgas S.R. \& Rodrigues M.T. (2015) Biogeographic history and cryptic diversity of saxicolous Tropiduridae lizards endemic to the semiarid Caatinga. BMC Evolutionary Biology, 15: 94. 